\title{
Massive Upper Gastrointestinal Bleeding Due To Giant Splenic Artery Aneurysm With Gastric Fistula
}

\author{
Mideye Fistülize Dev Splenik Arter Anevrizmasına Bağlı Masif Üst
}

Gastrointestinal Sistem Kanaması

\author{
Seçkin Akküçük', Akın Aydoğan', Hanefi Bayaroğulları' İbrahim Yetim' \\ ${ }^{1}$ Mustafa Kemal University, Faculty of Medicine, Department of General Surgery \\ ${ }^{2}$ Mustafa Kemal University, Faculty of Medicine, Department of Radiology.
}

\begin{abstract}
We aimed to report a case of a giant splenic artery aneurysm (SAA) with gastric fistula with the review of the literature. A female patient with splenic artery aneurysm was admitted to our hospital with abdominal pain and massive upper gastrointestinal bleeding. Hemorrhagic shock occurred. Despite the resuscitation, the patient died.

Splenic artery aneurysms are the most common visceral aneurysm occurring predominantly in females with a ratio of 4:1. Giant aneurysm with thrombosis of the splenic artery is an extremely rare clinical entity and its size rarely exceeds to 3 centimeters. Although they are usually asymptomatic, SAA are clinically important because of the possibility of life-threatening rupture. Interventions or surgical treatment is indicated for symptomatic and giant aneurysms. Early diagnosis and prompt intervention is necessary for success of treatment.
\end{abstract}

Keywords: Splenic artery; aneurysm; gastric fistula; hemorrhagic shock

Başvuru Tarihi: 19.09.2012 Kabul Tarihi: 07.11.2012
Özet

Nadir görülen mideye fistülize olmuş dev splenik arter anevrizmasına bağlı masif üst gastrointestinal sistem kanaması ile başvuran bir olguyu sunmayı istedik. Splenik arter anevrizması olan kadın hasta hastanemize karın ağrısı ve üst gastrointestinal sistem kanaması ile getirildi. Hastada hemorojik şok mevcuttu. Yapılan tüm resusitasyon çabalarına rağmen hasta hayatını kaybetti.

Splenik arter anevrizmaları nadir görülmekle birlikte, kadınlarda erkeklere göre 4 kat daha fazla görülen ve iç organ anevrizmaları içerisinde en sık karşılaşılan anevrizmalardır. Splenik arterin tromboze ve dev anevrizmaları ise oldukça ender görülüp, nadiren 3 cm'ye ulaşırlar. Genellikle asemptomatik olsalar da, hayatı tehdit edebilecek yırtılmaları nedeniyle klinik olarak oldukça önemlidirler. Bu hastaların tedavisindeki başarıda, erken tanı, cerrahi ya da diğer girişimsel yöntemler önemlidir.

Anahtar Kelimeler: Splenik arter; anevrizma; mide fistülü; hemorojik şok

Aplication: 19.09.2012 Accepted: 07.11.2012

autopsy series ${ }^{1-3}$. Etiology is unknown. They are usually asymptomatic but clinical presentation of a splenic artery aneurysm is variable. Rupture and fatal hemorrhage are the most important complications. The aneurysm is usually found incidentally on imaging studies. Computed tomography (CT), magnetic resonance imaging and color Doppler ultrasonography are the imaging technics 
that are used most frequently ${ }^{4}$. Giant splenic artery aneurysms and their fistulas to stomach are extremely rare.

\section{Case Report}

Seventy-seven years old female patient was admitted to our hospital with left hypochondriac pain, melena and hematemesis. Patient was hypertensive and diabetic according to her medical history. She was treated in coronary intensive care unit for 10 days due to myocardial infarction in another medical center, and discharged 1 week ago. She had massive upper gastrointestinal bleeding a day ago. The patient had stopped bleeding at the first examine in our emergency unit. She was hospitalized with the symptoms and signs of hypovolemia. The patient was transfused with 4 units of erythrocyte suspension and enough colloids. Forty milligrams of intravenous pantoprazole per day was also given. After hemodynamic stabilization, the patient was initially evaluated with abdominal ultrasonography (USG) and color Doppler ultrasonography study. USG revealed cystic lesion on the left side of abdomen in the region of tail of pancreas and at splenic hilum. The wall of cyst was thick with heterogeneous echogenicity. On color Doppler ultrasonography study, complete filling of color in the lesions was seen. Pulse wave study confirmed the arterial flow pattern. CT study was planned for abdominal imaging and a multislice computed tomography (MSCT) scan with contrast revealed $5.4 \times 5.3 \mathrm{~mm}$ centimeters aneurismal dilatation at the distal third of the splenic artery with intraluminal thrombus formation (Figure1). Aneurysm was embedded into the wall of stomach. Esophagogastro-duodenoscopy revealed mass effect of the aneurysm in the lumen of stomach and bleeding fistula (Figure 2). The fistula was located at the $1 / 3$ proximal posterior wall of the corpus of stomach. She was examined for about a week, and no more bleeding occurred. Because of high risk for morbidity and mortality due to coronary arterial disease, the patient and her relatives refused any invasive procedures to the aneurysm. She was discharged with medications for gastric acid and mucosa. Fifteen days after her discharge, the bleeding occurred again. She was admitted to our hospital with hemorrhagic shock. Despite all the treatment trials, her hemodynamic stabilization could not be achieved. Cardiac arrest occurred. Despite the resuscitation, the patient died.

Figure 1 : Multislice computed tomography view of the splenic artery aneurysm

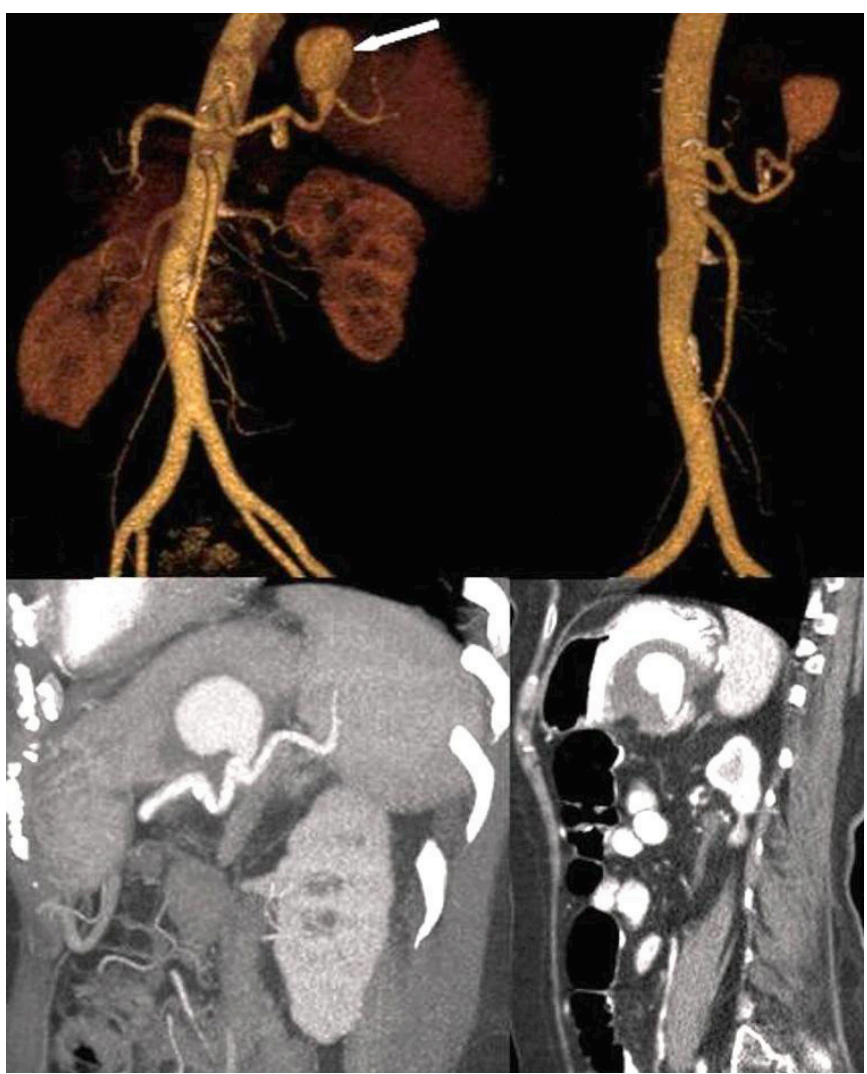

Figure 2 : Endoscopic view of the gastric fistula of the splenic artery aneurysm.

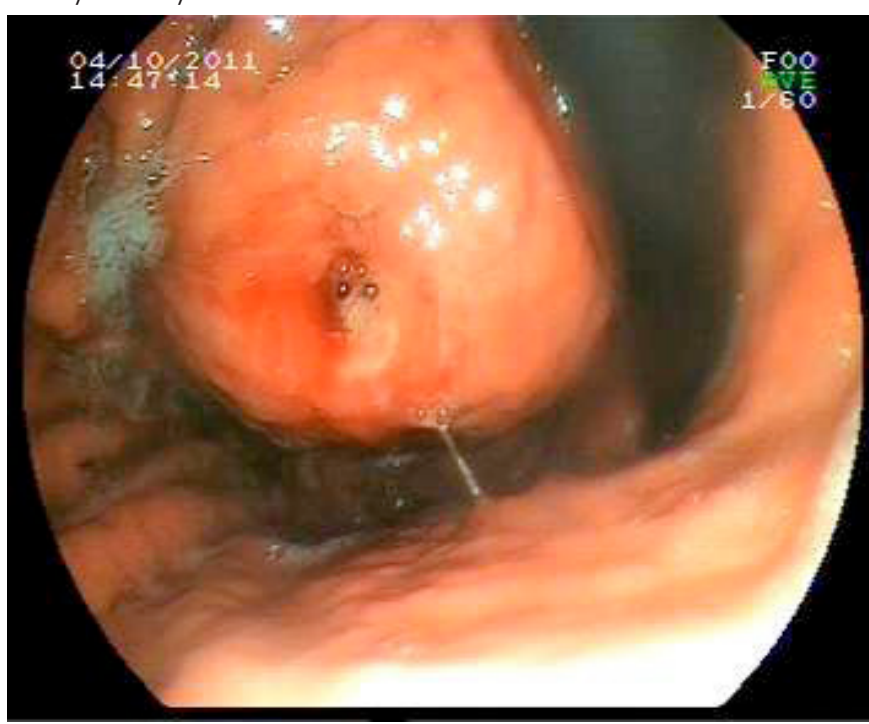




\section{Discussion}

Splenic artery aneurysms are the most frequent pattern of the visceral artery aneurysms, with an incidence of approximately $60 \%$. The prevalence of SAA differs from $0.01 \%$ to $10.4 \%$ in autopsy studies ${ }^{1}$. However SAAs larger than 3 centimeters are rare, some giant aneurysms larger than $10 \mathrm{~cm}$ have been reported ${ }^{2}$. SAA is usually single and saccular and it is commonly located in the middle and distal part of the splenic artery. SAAs occur most often at bifurcations of the distal part of SA ${ }^{1,5}$. Aneurysm of the patient in this study was at the distal part of SA.

Splenic artery aneurysm can be diagnosed at any age with mean age presentations of 52 years. It is predominant in females with a ratio of $4: 1^{1,5}$. The pathogenesis of splenic artery aneurysm is not fully understood. It may be congenital or acquired. Some suspected etiological factors are atherosclerosis, focal arterial inflammation, pancreatitis, hypersplenism, portal hypertension and trauma, hormonal and hemodynamic changes due to pregnancy ${ }^{1,4,6}$.

Most patients are asymptomatic and aneurysms are found incidentally on imaging studies. Among symptomatic patients, epigastric or left upper quadrant pain is the leading complaint 1,5,7. Occasionally, the aneurysm can erode into adjacent viscus and may be presented as gastrointestinal hemorrhage ${ }^{4,7}$. Although the rupture or fistula is very rare, these symptoms can cause severe sitiuations. Rupture of the aneurysm causes severe abdominal pain and hemorrhagic shock. The reported risk of rupture varies from $3 \%$ to $10 \%$ and mortality rate is $36 \%$ in non-pregnant patient. The risk of rupture and mortality rate is much higher in pregnant patient $1,4,7$. Our case had left upper quadrant pain and upper gastrointestinal bleeding. Eroded wall of the stomach and the fistula was demonstrated with MSCT and esophagogastroduodenoscopy studies. Computed tomography, magnetic resonance imaging, conventional angiography and color Doppler ultrasonography are used most frequently for diagnosis ${ }^{1,3,4}$. The gold standard for the diagnosis of SAA is arterial angiography, but MSCT angiography provides necessary information for the diagnosis ${ }^{3}$.

Treatment is recommended for patient with symptomatic or enlarging aneurysms and for all pregnant patients due to the risk for rupture. Conventional open surgery, endovascular treatment and laparoscopic surgery are the methods of therapy. The choice of treatment should be done according to the site, the type and the symptoms of aneurysms ${ }^{4,5,7}$. We planned to perform embolization of the aneurysm. Since the patient had coronary artery disease, she denied the procedure due to the high risk of morbidity and mortality.

\section{Conclusion}

Giant SAAs are rare lesions but they have potential risk of rupture and hemorrhage. Interventions or surgical treatment is indicated for symptomatic and giant aneurysms. Early diagnosis and prompt intervention is necessary for success of treatment.

The authors warrant that, there is no financial relationship with any organizations or company. 


\section{Kaynaklar}

1. Selo-Ojeme DO, Welch CC. Review: Spontaneous rupture of splenic artery aneurysm in pregnancy. Eur J Obstet Gynecol Reprod Biol 2003; 109(2):124-127.

2. I. H.Huang, D. A. Zuckerman, and J. B Matthews. Occlusion of a giant splenic artery pseudoaneurysm with percutaneous thrombin-collagen injection. J Vasc Surg 2004; 40 (3):574-577.

3. Halloul Z, Meyer F, Grote R, Lippert H, Buerger T. Selective embolization of splenic artery aneurysm - case report. Eur Surg 2005; 37(1): 59-62.

4. Chadha M, Ahuja C. Visceral artery aneurysms: Diagnosis and percutaneous management. Semin Intervent Radiol. 2009; 26(3):196-206.

5. Carmeci C, McClenathan J. Visceral artery aneurysms as seen in a community hospital. Am J Surg. 2000; 179(6): 486-489.

6. Siablis D, Papathanassiou ZG, Karnabatidis D, Christeas N, Katsanos K, Vagianos C. Splenic arteriovenous fistula and sudden onset of portal hypertension as complications of a ruptured splenic artery aneurysm: Successful treatment with transcathather arterial embolization. A case study and review of the literature. World J Gastroenterol 2006; 12(26): 4264-4266.

7. Carr SC, Mahvi DM, Hoch JR, Archer CW, Turnipseed WD. Visceral artery aneurysm rupture. J Vasc Surg 2001;33(4): 806866. 